\title{
Visceral Leishmaniasis Associated with Macrophage Activation Syndrome and Diffuse Alveolar Hemorrhage in a Lupus Patient
}

\section{Leishmaniose Visceral Associada a Síndrome de Ativação Macrofágica e a Hemorragia Alveolar Difusa numa Doente com Lupus}

\author{
Andreia COSTA $\triangle^{1}$, Cármen PAIS ${ }^{1}$, Sofia CERQUEIRA ${ }^{1}$, Fernando SALVADOR ${ }^{1}$ \\ Acta Med Port 2018 Oct;31(10):593-596 - https://doi.org/10.20344/amp.9028
}

\begin{abstract}
Systemic lupus erythematosus is a heterogeneous and unpredictable autoimmune disease which can be complicated to approach and treat. Hemophagocytic lymphohistiocytosis and diffuse alveolar hemorrhage are rare disease complications. The authors describe a clinical case of a 32-year-old woman with lupus and fever of unknown origin. From the investigations performed, the myelogram revealed hemophagocytosis and Leishmania parasites, therefore liposomal amphotericin B was then started. In addition to directed therapy, she maintained fever that evolved with diffuse alveolar hemorrhage. The myelogram was repeated and showed that she still had hemophagocytosis but now without parasites. Corticotherapy was increased and intravenous Immunoglobulin was started, with improvement. Rituximab was started as a result of macrophage activation syndrome and diffuse alveolar hemorrhage. Months after discharge, she began once again to have sustained fever and Leishmania parasites were found again, therefore liposomal amphotericin B was started once more associated with miltefosine. She continues being followed-up as she is asymptomatic and using steroids in weaning scheme.
\end{abstract}

Keywords: Leishmaniasis, Visceral; Lung Diseases; Lymphohistiocytosis, Hemophagocytic; Lupus Erythematosus, Systemic/complications; Macrophage Activation Syndrome; Treatment Outcome

\section{RESUMO}

O lúpus eritematoso sistémico é uma doença autoimune heterogénea e imprevisível, o que pode complicar a sua abordagem e tratamento. A linfohistiocitose hemofagocítica e a hemorragia alveolar difusa são complicações raras da doença. Os autores descrevem o caso de uma mulher de 32 anos, com lúpus e febre de origem indeterminada. Da investigação realizada, o mielograma revelou hemofagocitose e parasitas de Leishmania, pelo que iniciou anfotericina B lipossomal. Manteve febre apesar da terapêutica dirigida e evoluiu com hemorragia alveolar difusa. Repetiu mielograma, mantendo hemofagocitose já sem parasitas, tendo aumentado corticoterapia e iniciado imunoglobulina com melhoria. Dada a presença de síndrome de activação macrofágica e hemorragia alveolar difusa iniciou rituximab. Meses após a alta hospitalar, iniciou novamente febre sustentada e foram novamente identificados parasitas de Leishmania, pelo que reiniciou anfotericina B lipossomal associada a miltefosina. Mantém follow-up, encontrando-se assintomática e com corticóides em esquema de desmame.

Palavras-chave: Doenças do Pulmão; Leishmaniose Visceral; Linfohistiocitose Hemofagocítica; Lúpus Eritematoso Sistémico/complicações; Resultado do Tratamento; Síndrome de Ativação Macrofágica

\section{INTRODUCTION}

Systemic lupus erythematosus (SLE) is an autoimmune disease with a heterogeneous clinical course, characterized by periods of remission and relapse, with different degrees of severity that can affect any organ. ${ }^{1}$ Hemophagocytic lymphohistiocytosis $(\mathrm{HLH})$ and diffuse alveolar hemorrhage (DAH) can be complications of this disease. ${ }^{2,3}$

This clinical case demonstrates the complexity of a patient with SLE who evolved with multiple and rare complications, including visceral leishmaniasis, macrophage activation syndrome (MAS) and DAH, and whose diagnostic and therapeutic approach was a constant challenge.

\section{CLINICAL CASE}

The authors describe a clinical case of a 32-years-old woman with SLE since 2006, with cutaneous, articular and renal involvement, a SLICC/ACR damage index of 3 and a SLEDAI of 7 . She is under treatment with $20 \mathrm{mg}$ of prednisolone (PDN) in weaning scheme. She was in a regular Hemodialysis program as a result of lupus nephritis. She previously underwent several treatment regimens (cyclophosphamide, mycophenolate mofetil, cyclosporin and human intravenous immunoglobulin), always with disease progression.

She had previous multiple infectious, mostly central venous catheter (CVC) infections, in recent weeks, as well as lupus flares with fever and elevated inflammation markers, and was treated only with an increase in the doseage of corticosteroids.

In early December 2015 she went to the Emergency Room with fever, which had been developing for four months, hematemesis and melena. Anemia was identified $(\mathrm{Hb} 5.88 \mathrm{~g} / \mathrm{dL})$ and transfusion support was performed. Upper endoscopy revealed a pylorus ulcer of $8 \mathrm{~mm}$ without active bleeding, associated with PDN and non-steroidal

\footnotetext{
1. Serviço de Medicina Interna. Centro Hospitalar de Trás-os-Montes e Alto Douro. Vila Real. Portugal.

$\triangle$ Autor correspondente: Andreia Costa. andreia_inha2@hotmail.com

Recebido: 01 de abril de 2017 - Aceite: 16 de agosto de 2018 | Copyright (C) Ordem dos Médicos 2018
} 
anti-inflammatory drug use.

Laboratory tests (Table 1) showed pancytopenia, increased inflammatory parameters, normal coagulation parameters, normal haptoglobin and the peripheral blood smear did not show morphological changes. Ferritin was very high, $2309 \mathrm{ng} / \mathrm{mL}$, and hypertriglyceridemia was 560 $\mathrm{mg} / \mathrm{dL}$.

Polymerase chain reaction for Mycobacterium tuberculosis, HBV, HCV and HIV was negative, as well as other requested serologies (syphilis, rubella, Paul Bunnell, CMV, Widal, Wright, Rose Bengal and Rickettsia).

Ds-DNA was elevated and complement was decreased.

The chest radiograph was normal and the abdominal and pelvic computerized tomography (CT) revealed a homogeneous splenomegaly. The transthoracic/transesophageal echocardiogram excluded endocarditis.

On suspicion of CVC infection, she was started on ceftazidime and daptomycin and the CVC was removed a few days later. A new tunneled right femoral CVC was placed.

HLH was then suspected and a myelogram was performed. Hemophagocytosis (Fig. 1) and many Leishmania parasites (Fig. 2) were found. The Leishmania serology ( $\lg G$ and $\operatorname{lgM}$ ) was also positive.

She had also 41/mm $\mathrm{mK}^{3}$ lymphocytes (N: 90 - 590) and 165/mm³ CD4 (N: 410 - 1590).

HLH associated with visceral leishmaniasis (Kala-azar) was assumed, fulfilling the HLH 2004 criteria and with a HScore 2014 of 242 (99\% probability) (Table 2).

The epidemiological data were reviewed and contact with a dog with a possible leishmania infection was reported in June/July 2015.

She started liposomal amphotericin B (4 mg/kg on days 1 - 5, 10, 17, 24, 31 and 38 - total dose of $40 \mathrm{mg} / \mathrm{kg}$ ).

After two weeks she maintained fever, pancytopenia, hyperferritinemia, hypertriglyceridemia as well as elevated inflammatory parameters (Table 1). She maintained high ds-DNA and complement consumption. The chest CT scan showed new bilateral pulmonary infiltrates in ground glass and the bronchoscopy with bronchoalveolar lavage revealed macrophages with hemosiderin inclusions, Golden Score 315. Microbiology was negative.

Bone marrow examination was repeated showing hemophagocytosis, without parasites. Simultaneously, her general condition deteriorated and she developed hypotension and respiratory failure requiring adrenergic support and noninvasive ventilation. Klebsiella pneumoniae carbapenemase-producing bacteria were then isolated in blood cultures and in the hemodialysis catheter. This catheter was

Table 1 - Laboratory tests during hospitalization and in outpatient follow-up

\begin{tabular}{|c|c|c|c|c|c|c|c|}
\hline & 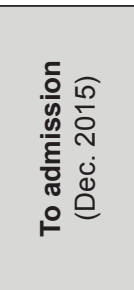 & & 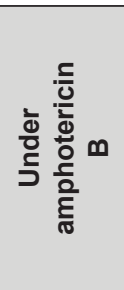 & 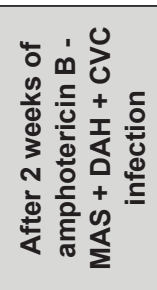 & 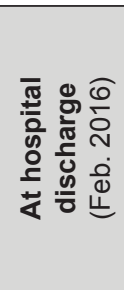 & 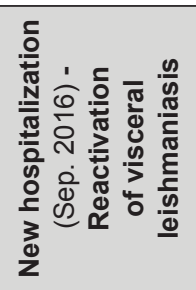 & 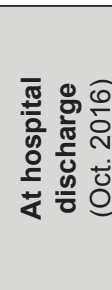 \\
\hline $\begin{array}{l}\text { Hemoglobin (g/dl) } \\
(\mathrm{N}: 12-16)\end{array}$ & 5.88 & \multirow{7}{*}{ 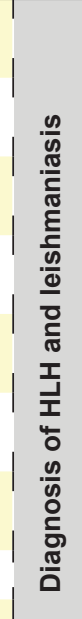 } & 10.23 & 7.5 & 10.89 & 9.7 & 8.7 \\
\hline $\begin{array}{l}\text { Leukocytes (cel/uL) } \\
\text { (N: } 4 \text { - 11) }\end{array}$ & 2600 & & 3000 & 2600 & 6100 & 2200 & 3000 \\
\hline $\begin{array}{l}\text { Platelet (cel/uL) } \\
(\mathrm{N}: 150-400)\end{array}$ & 66000 & & 89000 & 85000 & 174000 & 101000 & 177000 \\
\hline $\begin{array}{l}\text { C-reactive protein }(\mathrm{mg} / \mathrm{dL}) \\
(\mathrm{N}:<0.5)\end{array}$ & 7.2 & & 1.9 & 34 & 1.6 & 2.2 & 1.6 \\
\hline $\begin{array}{l}\text { Erythrocyte sedimentation rate }(\mathrm{mm} / \mathrm{h}) \\
(\mathrm{N}:<10)\end{array}$ & 40 & & & 110 & & 15 & \\
\hline $\begin{array}{l}\text { Ferritin }(\mathrm{ng} / \mathrm{mL}) \\
(\mathrm{N}: 10-291)\end{array}$ & 2309 & & 1411 & 1598 & 641 & 1869 & 615 \\
\hline $\begin{array}{l}\text { Triglycerides }(\mathrm{mg} / \mathrm{dL}) \\
(\mathrm{N}:<150)\end{array}$ & 560 & & 513 & 488 & 275 & 245 & 230 \\
\hline Antinuclear antibodies & $1: 1280$ & & & & & & \\
\hline $\begin{array}{l}\text { Anti-dsDNA (Ul/mL) } \\
(\mathrm{N}:<10)\end{array}$ & $>379$ & & & $>379$ & 77 & 75 & 60 \\
\hline $\begin{array}{l}\text { Complement C3 / C4 (mg/dL) } \\
\text { (N: } 90-180 / 12-36)\end{array}$ & $25 / 6$ & & & $38 /<6$ & $87 / 14$ & $67 / 14$ & $85 / 19$ \\
\hline Antiphospholipid antibodies & Negative & & & & & & \\
\hline Immunoglobulins (IgG, IgM, IgA, IgE) & Normal & & & & & & \\
\hline
\end{tabular}




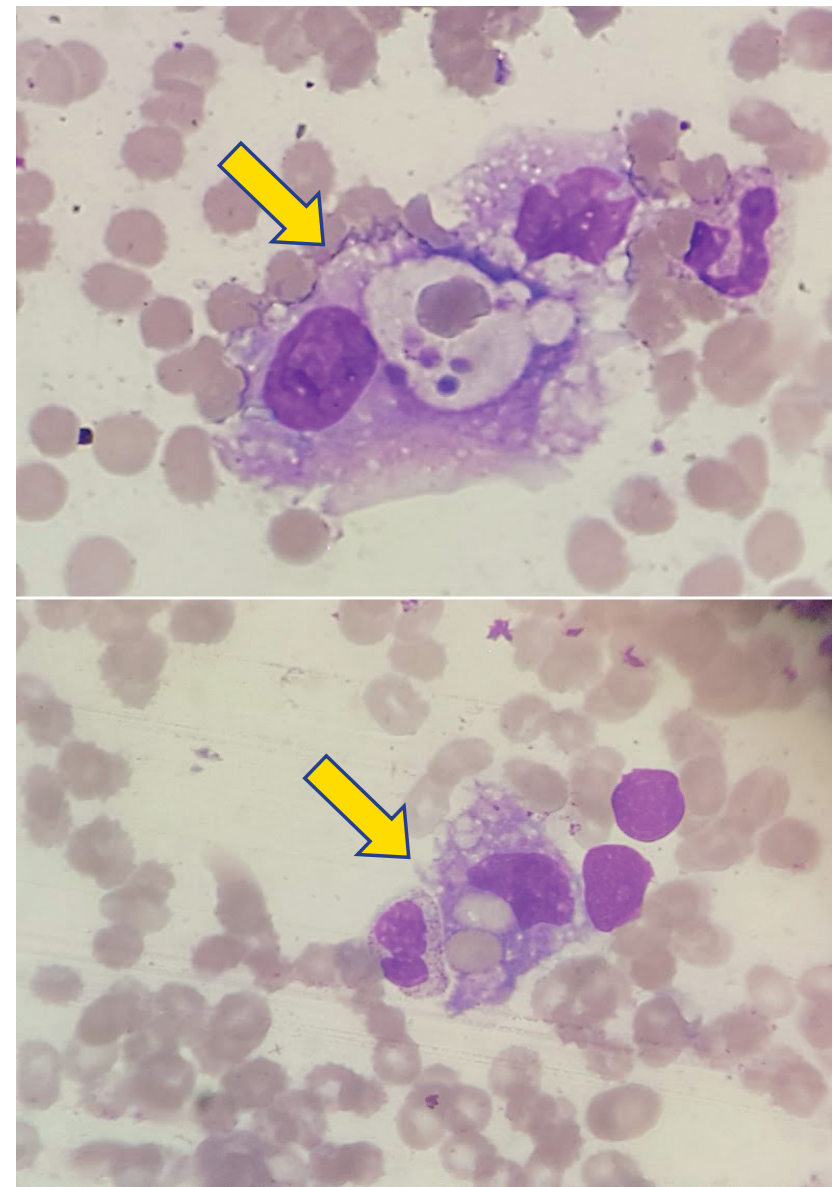

Figure 1 - Hemophagocytosis

thus removed and antibiotic therapy with meropenem and colistin was initiated. Prednisolone dose was increased to 2 $\mathrm{mg} / \mathrm{kg} /$ day (previously with $30 \mathrm{mg}$ ) and intravenous human immunoglobulin $400 \mathrm{mg} / \mathrm{kg} /$ day for five days was started due to DAH and MAS that was also diagnosed (HLH associated with rheumatic diseases). In the meantime she was diagnosed with a concomitant infection too.

During this period, a skin injury was identified on the external face of the left leg. Infectious panniculitis was assumed and the biopsy was compatible (Fig. 3).

She evolved with sustained apyrexia, reduction of

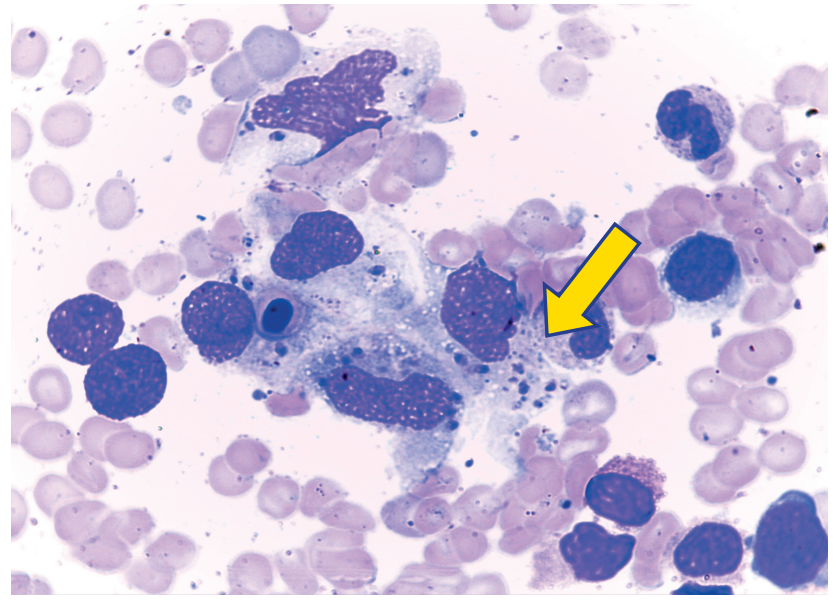

Figure 2 - Leishmania amastigotes

inflammatory parameters and persistently negative cultures.

Afterwards she underwent rituximab $375 \mathrm{mg} / \mathrm{m}^{2}$ treatment for four weeks.

She became asymptomatic, with clinical and laboratory improvement and maintained B-cell depletion, with steroids in a weaning scheme (prednisolone nearly $5 \mathrm{mg} /$ day). DsDNA progressively reduced and complement levels increased to almost normal values.

Despite initial improvement, seven months after discharge she had sustained fever once again. She was readmitted, with pancytopenia, hyperferritinemia and homogeneous splenomegaly.

The bone marrow was reexamined and Leishmania parasites were again found. We started liposomal amphotericin B and Miltefosine $50 \mathrm{mg}$ bid 28 days once again.

She evolved well with sustained apyrexia, and resolution of the pancytopenia. We decided to continue liposomal amphotericin B (3 mg/kg) every three weeks until resolution of immunosuppression.

\section{DISCUSSION}

$\mathrm{HLH}$ is an aggressive and potentially fatal disease. ${ }^{2,4,5}$ A febrile syndrome of unknown origin with multi organ involvement should alert us to this possibility. In this case, the combination of fever with pancytopenia, hyperferritinemia,

Table 2 - The HScore: score for the diagnosis of reactive hemophagocytic syndrome $-2014^{14}$

\begin{tabular}{|c|c|}
\hline Parameter & No of points (criteria for scoring) \\
\hline Known underlying immunosuppression* & 0 (no) or 18 (yes) \\
\hline Temperature $\left({ }^{\circ} \mathrm{C}\right)$ & $0(<38.4), 33(38.4-39.4)$, or $49(>39.4)$ \\
\hline Organomegaly & $\begin{array}{l}0 \text { (no), } 23 \text { (hepatomegaly or splenomegaly), or } 38 \text { (hepatomegaly and } \\
\text { splenomegaly) }\end{array}$ \\
\hline No. of cytopenias $\dagger$ & 0 (1 lineage), 24 (2 lineages), or 34 (3 lineages) \\
\hline Ferritin (ng/mL) & $0(<2.000), 35(2.000-6.000)$, or $50(>6.000)$ \\
\hline Triglyceride (mmoles/L) & $0(<1.5), 44(1.5-4)$, or $64(>4)$ \\
\hline Fibrinogen (gm/L) & $0(>2.5)$ or $30(\leq 2.5)$ \\
\hline Serum glutamic oxaloacetic transaminase (IU/L) & $0(<30)$ or $19(\geq 30)$ \\
\hline Hemophagocytosis features on bone marrow aspirate & 0 (no) or 35 (yes) \\
\hline
\end{tabular}

\footnotetext{
* Human immunodeficiency virus positive or receiving long-term immunosuppressive therapy (i.e., glucocorticoids, cyclosporine, azathioprine).
}

† Defined as a hemoglobin level of $\leq 9.2 \mathrm{gm} / \mathrm{dL}$ and/or a leukocyte count of $\leq 5.000 / \mathrm{mm}^{3}$ and/or a platelet count of $\leq 110000 / \mathrm{mm}^{3}$. 


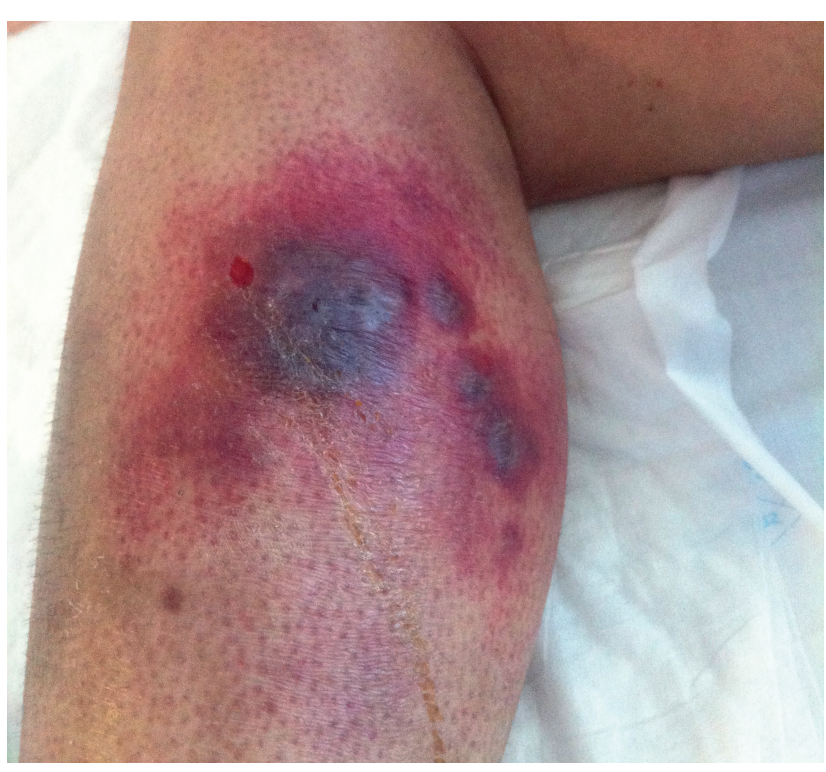

Figure 3 - Infectious panniculitis

hypertriglyceridemia and splenomegaly raised this suspicion. Hemophagocytosis was also found on bone marrow examination.

Non-response to directed treatment was verified, the study was continued and culminated in the diagnosis of another rare but life-threatening complication of SLE, with a high early mortality rate: DAH. Taking into account laboratory markers of lupus activity and $\mathrm{HLH}$, a MAS was simultaneously assumed.

Specific therapy is based on agressive immunossupressive treatment. Due to a severe clinical situation and concomitant infection, it was decided to initiate intravenous immunoglobulin and then rituximab.

Despite lack of data on rituximab and intravenous immunoglobulin, there are some case reports that show its benefits in SLE, particularly in severe and refractory disease.
There is also some evidence of rituximab in preventing recurrences of DAH in patients with lupus. . $^{3,6,7,8}$

Due to reactivation of Leishmania infection, despite scant information in the literature, we have decided to maintain prophylaxis with liposomal amphotericin B while the patient was B cell depleted, in a similar way to what is recommended for HIV infection. ${ }^{9,10-14}$

This case underlines the complexity and difficulty of diagnosis. It was a constant challenge taking into account the rare and life-threatening complications of SLE, like HLH (associated with leishmaniasis or autoimmune disease) and $\mathrm{DAH}$. The association of infectious complications made clinical reasoning and targeted treatment more difficult.

\section{PROTECTION OF HUMANS AND ANIMALS}

The authors declare that the procedures were followed according to the regulations established by the Clinical Research and Ethics Committee and to the Helsinki Declaration of the World Medical Association.

\section{DATA CONFIDENTIALITY}

The authors declare having followed the protocols in use at their working center regarding patients' data publication.

\section{PATIENT CONSENT}

Obtained.

\section{CONFLICTS OF INTEREST}

The authors report no conflict of interest.

\section{FUNDING SOURCES}

This research received no specific grant from any funding agency in the public, commercial, or not-for-profit sectors.

8. Martínez-Martínez MU, Abud-Mendoza C. Recurrent diffuse alveolar haemorrhage in a patient with systemic lupus erythematosus: long-term benefit of rituximab. Lupus. 2012;21:1124.

9. McQuarrie S, Kasper K, Moffatt DC, Marko D, Keynan Y. Relapse of visceral leishmaniasis in an HIV-infected patient successfully treated with a combination of miltefosine and amphotericin B. Can J Infect Dis Med Microbiol. 2015;26:325-9.

10. Lindoso JA, Cunha MA, Queiroz IT, Moreira CH. Leishmaniasis - HIV coinfection: current challenges. HIV AIDS. 2016;8:147-56.

11. Bern C. Clinical manifestations and diagnosis of visceral leishmaniasis. Up to date [Acessed 2016 April 19]. Available from: http://www.uptodate. com.

12. Murray HW. Treatment of visceral leishmaniasis in 2004. Am J Trop Med Hyg. 2004;71:787.

13. Rajagopala S, Dutta U, Chandra KS, Varma N, Kochhar R. Visceral leishmaniasis associated hemophagocytic lymphohistiocytosis--case report and systematic review. J Infect. 2008;56:381.

14. Fardet L, Galicier L, Lambotte O, Marzac C, Aumont C, Chahwan D, et al. Development and validation of the HScore, a score for the diagnosis of reactive hemophagocytic syndrome. Arthritis Rheumatol. 2014;66:2613-20. 